\title{
Prosecuting Crimes against Humanity before International Crimes Tribunal in Bangladesh: A Nexus with an Armed Conflict
}

\author{
Yudan Tan*
}

The International Crimes Tribunal in Bangladesh was created in 2010 under the amended International Crimes (Tribunals) Act 1973 (1973 Act) to deal with international crimes, including crimes against humanity committed during the liberation war of 1971. Scholars and the international community have voiced legitimacy concerns that the Tribunal's trial will not be fair, transparent or impartial for its inconsistency with international standards concerning the definitions of crimes, evidentiary rules, death penalty, compensation to victims, and the selection of judges. ${ }^{1}$ Instead of analysing the legitimacy issues, this article mainly aims to examine the issue of a nexus with an armed conflict for crimes against humanity from Third World Approaches to International Law (TWAIL) $)^{2}$ perspective.

According to TWAIL, as Antony Anghie wrote, international law has been used to discipline and subordinate non-European peoples. "[T]hese doctrines

* Postdoc at the International Academy of the Red Cross and Red Crescent in Soochow University, China.

1 Zakia Afrin, The International War Crimes (Tribunal) Act, 1973 of Bangladesh, INDiAN Yearbook of International LaW and Policy 341 (2009); Bianca Karim \& Tirza Theunissen, Bangladesh, in International Law and Domestic Legal Systems: Incorporation, Transformation, And Persuasion 114 (Dinah Shelton ed., 2011); Bangladesh: Upgrade War Crimes Law, Human Rights Watch (July 8, 20o9), https:// www.hrw.org/news/2009/07/o8/bangladesh-upgrade-war-crimes-law; Letter to Prime Minister Sheikh Hasina Re: International Crimes (Tribunals) Act, Human Rig hts Watch (July 8, 2009), https://www.hrw.org/news/2009/o7/o8/letter-prime-minister-sheikh-hasina -re-international-crimes-tribunals-act; HuMAN Rights WATCH, IgNORING ExECUTIONS and Torture: Impunity for BAngladesh's Security Forces (2009), https:// www.hrw.org/sites/default/files/reports/bangladesho5ogwebwcover.pdf; Abdur Razzaq, The Tribunals in Bangladesh: Falling Short of International Standards, in TRIALS FOR International Crimes in Asia 346 (Kirsten Sellars ed., 2015).

2 Antony Anghie \& B.S. Chimni, Third World Approaches to International Law and Individual Responsibility in Internal Conflicts, 2 Chinese Journal of International LaW 77 (2003). 
[of international law] were created for the explicit purpose of excluding the colonial world, or else, are based on an exclusion ... as when positivist jurists dismiss the state practice of the uncivilized Eastern states as irrelevant to the formulation of international law". ${ }^{3}$ The field of international criminal law is not an exception. The Third World's participation is less concerned for the formation of norms in this field. The design of crime definitions, attribution doctrines, and procedural norms in international criminal law are not neutral. ${ }^{4}$ In addition to this, scholars noted that due to the human rights movement, norms of international criminal law also concern the interest of ordinary people from the post-colonial world. Rules and institutions of international criminal law sometimes unequally facilitate Third World governments to prosecute international crimes committed by opposing non-State entities of Third World States. ${ }^{5}$ The practice of international criminal justice is criticised for its selectivity ${ }^{6}$ and double standards. ${ }^{7}$

It is less controversial that the notion of crimes against humanity is considered as an international crime. It is also generally asserted that the crime against humanity is disassociated with a nexus with an armed conflict under customary law now. However, it is not clear as to whether the crime was disassociated with the nexus before or in the liberation war of 1971. This question is less concerned by European-colonial States, while it still plays a crucial role in prosecuting crimes against humanity committed in Bangladesh. When the amended 1973 Act, applied to prosecuting crimes committed in 1971, was adopted or approved (ex post facto law), an observation on these crimes under customary law at the material time is of importance. This article analyses the issue of the nexus with an armed conflict for crimes against humanity in the Bangladeshi Tribunals at the material time. The central question here is whether the notion of crimes against humanity required a nexus with an armed conflict before or in 1971.

3 Antony Anghie, Imperialism, Sovereignty and the Making of International LAW 315 (2005).

4 Sergey Vasiliev, The Crises and Critiques of International Criminal Justice, in ThE OXForD Handbook of International Criminal LaW 25 (Kevin Heller et al. eds., forthcoming 2020).

5 Asad G. Kiyani, Third World Approaches to International Criminal Law, 109 American Journal of International LaW Unbound 255 (2015).

6 Kiyani, supra note 5; Asad Kiyani, Group-Based Differentiation and Local Repression: The Custom and Curse of Selectivity, 14 Journal of International Criminal Justice 939 (2016); John Reynolds \& Sujith Xavier, 'The Dark Corners of the World': TWAIL and International Criminal Justice, 14 Journal of International Criminal Justice 959 (2016).

7 Wolfgang Kaleck, Double Standards: International Criminal law and the WEST 109-17 (2015). 
This article consists of five sections including this introduction and conclusion. Section II analyses the 1973 Act and the practice of Bangladeshi Tribunals in relation to prosecuting crimes against humanity. Section III analyses the issue of whether the notion of crimes against humanity required a nexus with an armed conflict as a legal element in customary law. This section involves a historical survey on how the powerful States have shaped the notion of crimes against humanity and defined a nexus with an armed conflict under customary law. Section IV discusses the disappearance of a nexus with an armed conflict for crimes against humanity under customary law. In closing, Section v highlights final conclusions.

Crimes against Humanity before the International Crimes Tribunal in Bangladesh

In order to better understand the background of prosecution of international crimes in Bangladesh, this section firstly examines the establishment of the International Crimes Tribunals, and then briefly analyses the nexus issue for crimes against humanity.

The establishment of the International Crimes Tribunals in Bangladesh is pertinent to the Bangladesh Liberation War, which lasted for about nine months from 26 March to 16 December in 1971. It has been reported that crimes under international law, including large-scale killing, torture, rape, and persecution, were committed during the war. ${ }^{8}$ Accordingly, the Bangladesh Government passed the 1973 Act. The 1973 Act provides "for the detention, prosecution and punishment of persons for genocide, crimes against humanity, war crimes and other crimes under international law". ${ }^{9}$ There existed investigations of war crimes committed by members of the Pakistan Army, but no one was convicted under this Act due to a tripartite agreement among Pakistan, Bangladesh, and India. Some collaborators of the Pakistan Army were tried in a separate process under the 1972 Bangladesh Collaborators (Special Tribunals) Order, but most of them were released according to the 1973 governmental clemency. ${ }^{10}$ The 1973 Act laid dormant for almost four decades, and no

8 Rounaq Jahan, Genocide in Bangladesh, in Century of Genocide: Critical Essays And Eyewitness Accounts 245-53 (Samuel Totten \& William S. Parsons eds., 3rd ed. 2009).

9 The International Crimes (Tribunals) Act 1973 (Act No. XIX of 1973) (Bangl.).

10 Human Rights Watch, supra note 1, at 12. 
proceeding took off to bring perpetrators of these crimes to justice until the Bangladesh Government decided to try war criminals in 2009. ${ }^{11}$ The 1973 Act was slightly amended by the International Crimes (Tribunals) (Amendment) Act 2009. ${ }^{12}$ According to the 1973 Act, as amended in 2009, an International Crimes Tribunal was created to deal with crimes committed since the 1971 Liberation War. As a result, the International Crimes Tribunal-1 (ICT-1) and International Crimes Tribunal-2 (ICT-2) were established in 2010 and 2012 respectively. The Appellate Division of the Bangladesh Supreme Court has jurisdiction to hear and determine appeals from judgments of the two ICTs. ${ }^{13}$

With regard to the jurisdiction of the two ICTs, according to Section 3(1) of the 1973 Act, the two ICTs have:

[T] he power to try and punish any individual or group of individuals, or organizations, or any member of any armed, defence or auxiliary forces, irrespective of his nationality, who commits or has committed, in the territory of Bangladesh, whether before or after the commencement of this Act, any of the crimes mentioned in sub-section (2). ${ }^{14}$

The crimes mentioned in sub-section (2) covers crimes against humanity, crimes against peace, genocide, war crimes, violation of any humanitarian rules applicable in armed conflicts laid down in the Geneva Conventions of 1949, any other crimes under international law, attempt, abetment or conspiracy to commit any such crimes, and complicity in or failure to prevent commission of any such crimes. The notion of crimes against humanity under this Act is defined as follows:

Crimes against Humanity: namely, murder, extermination, enslavement, deportation, imprisonment, abduction, confinement, torture, rape or other inhumane acts committed against any civilian population or

11 International Commission of Jurists, The Events in East Pakistan, 1971 (1972); For a short history of the events and impunity, see HumAN Rig HTS WATCH, supra note 1, at 9-17; War Criminal Trial under Int'l Crime Act, DAILY StAR, (Mar. 26, 2009), http://www.thedailystar.net/story.php?nid=81408 (the Tribunal's jurisdiction is limited to "crimes committed within the territory of Bangladesh"; thus, crimes committed by Bangladeshi collaborators in Pakistan is not covered under the 1973 Act).

12 The International Crimes (Tribunals) (Amendment) Act 2009 (Act No. LV of 2009) (Bangl.).

13 The International Crimes (Tribunals) Act 1973 (Act No. XIX of 1973), § 21(1) (Bangl.).

$14 \quad I d . \S 3(1)$. 
persecutions on political, racial, ethnic or religious grounds, whether or not in violation of the domestic law of the country where perpetrated..$^{15}$

Obviously, a nexus with an armed conflict is not mentioned in this Act. A literal reading of the definition that the notion of crimes against humanity did not require a nexus with an armed conflict is less convincing. The following paragraphs resort to case law for clarification.

In practice, as of December 2019, the ICT-1 in Bangladesh has delivered 30 judgments. The ICT-2 has also delivered 11 judgments from 2012 to 2015, but it has not been functioning since September $2015 \cdot{ }^{16}$ Until now, 97 individuals have been convicted for charges of crimes against humanity, genocide, or war crimes by the two ICTs. ${ }^{17}$ Nearly all of the accused have been charged and convicted for crimes against humanity.

When clarifying its applicable law, the two Iстs first stressed that their applicable law 1973 Act is ex-post facto legislation. The tribunals added that ex-post facto legislation is permitted because international tribunals, for example, the two UN ad hoc tribunals, were constituted under retrospective statutes. ${ }^{18}$ The ICTs seem to ignore that the two ad hoc tribunals' jurisdiction over crimes is limited to crimes existent under customary international law. ${ }^{19}$ The main issue of ex-post facto legislation is not that the tribunal must be founded prospectively, but instead that the tribunal shall not apply law retrospectively so as to avoid violating the principle of legality. In the absence of relevant treaty or national criminal prohibitions in Bangladesh at the material time before or in 1971, how can its tribunals prosecute crimes against humanity without violating the principle of non-retroactivity, which prohibits domestic authorities interpreting a crime and its elements to convict persons retrospectively? The existing customary international rules play a vital role in this circumstance.

\footnotetext{
$15 \quad I d . \S 3(2)(\mathrm{a})$.

16 It is said that the ICT-2 was founded to speed up the work of the ICT-1.

17 Nearly half of the accused have been tried in absentia.

18 See Prosecutor v. Khan, Case No. o1 of 2013, Judgment, ๆף 71-72 (Int'l Crim. Trib. for Bangladesh Nov. 3, 2013); Prosecutor v. Qaiser, Case No. 04 of 2013, Judgment, I 363 (Int'l Crim. Trib. for Bangladesh Dec. 23, 2014); Mollah v. Government of Bangladesh, Case No. 24-25 of 2013, Judgment (Supreme Court of Bangladesh Sept. 17, 2013); Prosecutor v. Sattar, Case No. 55 of 2018, Judgment, ๆ 6 (Int'l Crim. Trib. for Bangladesh Dec. 11, 2019). This is not the place to discuss in detail whether customary international law is applicable at the two domestic tribunals.

19 Prosecutor v. Tadić, Case No. IT-94-1, Decision on Defence Motion for Interlocutory Appeal on Jurisdiction, \ 94 (Int'l Crim. Trib. for the Former Yugoslavia Oct. 2, 1995) (Tadić Appeals Chamber decision on jurisdiction).
} 
An appropriate understanding for applying the ex-post facto 1973 Act should be that these crimes enacted in the domestic law contain similar rules as those under customary law. Other scholars' observation also supports such an understanding, that courts in Bangladesh tend not to apply customary international law but instead give effect to domestic law containing similar norms. ${ }^{20}$ The two ICTS also reiterated the importance of customary international law. The ICTS clarified that they are domestic mechanisms set up to try crimes against humanity committed in violation of laws of war and customary law. They pointed out that " $[t]$ here is nothing repugnant to CIL [customary international law] in the Act of 1973, [...] [rather it] is consonant with the provisions of CIL".21 Thus, although customary law is not its applicable law, the ICTs have tried to construe legal elements of crimes against humanity in the 1973 Act to be consistent with that under customary law.

With regard to the nexus issue for crimes against humanity, the ICT-1 adopted two approaches in their judgments. Firstly, the ICT-1 in its early judgments repeatedly construed that:

Crime against humanity can be committed even in peacetime; the existence of armed conflict is, by definition, not mandatory. Neither in the preamble nor in the jurisdiction sections of the Act was it mentioned that crime against humanity requires the existence of an armed conflict.... However [,] no one denies the fact that there was an armed conflict in 197 . $^{22}$

$20 \quad$ Karim \& Theunissen, supra note 1 , at 106.

21 Mollah v. Government of Bangladesh, Case No. 24-25 of 2013, Judgment, at 132 (Supreme Court of Bangladesh Sept. 17, 2013).

22 Prosecutor v. Sayeedi, Case No. o1 of 2011, Judgment, I 32(1) (Int'l Crim. Trib. for Bangladesh Feb. 28, 2013); Prosecutor v. Azam, Case No. o6 of 2011, Judgment, If 32(1) (Int'l Crim. Trib. for Bangladesh July 15, 2013); Prosecutor v. Chowdhury, Case No. o2 of 2011, Judgment, I 33(1) (Int'l Crim. Trib. for Bangladesh Oct. 1, 2013); Prosecutor v. Nizami, Case No. 03 of 2011, ๆ 40 (Int'l Crim. Trib. for Bangladesh Oct. 29, 2014); Prosecutor v. Khokon, Case No. 04 of 2013, Judgment, ๆ 29 (Int'l Crim. Trib. for Bangladesh Nov. 13 2014); Prosecutor v. Hossain, Case No. o1 of 2013, Judgment, I 30 (Int'l Crim. Trib. for Bangladesh Nov. 24, 2014); Prosecutor v. Islam, Case No. 05 of 2013, Judgment, \ 4 (Int'l Crim. Trib. for Bangladesh Dec. 30 2014); Prosecutor v. Engineer, ICT-BD o1 of 2014, Judgment, If 4 (Int'l Crim. Trib. for Bangladesh Feb. 24, 2015); Prosecutor v. Hachhan, Case No. 02 of 2014, Judgment, I 4 (Int'l Crim. Trib. for Bangladesh June 9 2015); Prosecutor v. Haque, Case No. 03 of 2014, Judgment, If 4 (Int'l Crim. Trib. for Bangladesh Aug. 11 2015); Prosecutor v. Haque, Case No. 04 of 2014, Judgment, I 4 (Int'l Crim. Trib. for Bangladesh Feb. 2, 2016); Prosecutor v. Ahmd, Case No. o1 of 2015, Judgment, I 4 (Int'l Crim. Trib. for Bangladesh May 3, 2016); Prosecutor v. Rahman, Case No. o3 of 2015, Judgment, If 4 (Int'l Crim. Trib. for Bangladesh June 1, 2016); Prosecutor v. Haque, Case No. o2 of 2015, Judgment, If 4 (Int'l Crim. Trib. of Bangladesh July 18, 2016); Prosecutor v. Hossain, Case No. 04 of 2015, 
Accordingly, the ICT-1 confirmed that crimes against humanity require no nexus with an (international) armed conflict in 1971. There is no nexus of an armed conflict for crimes against humanity in 1971 under customary law. However, it is unclear whether the ICт-1 considered that the nexus was required before but that it disappeared in 1971. Secondly, the ICT-1 in its later judgments pointed out that the offences of crimes against humanity for which these accused are indicted are "recognized as international crimes as happened in war time situation". ${ }^{23}$ The tribunal did not mention the nexus issue for crimes against humanity under customary law in 1971 but simply referred to the fact of the existence of the war. It appears that the tribunals intentionally avoided to clarify the legal issue. If a nexus was required, a conviction of the crimes is consistent with the principle of legality because the nexus element was satisfied by the fact of the Liberation War; if a nexus was not required, the existence of the war was only a factual background. In this way, their convictions of crimes against humanity would not be challenged for the lack of a nexus with an armed conflict. Thus, the ICT-1 did not touch on the issue of whether crimes against humanity required an armed conflict nexus under customary law at the material time in 1971.

Unlike the ICT-1, the ICT-2 held that "[i]t is the 'context' [of the 1971 war of liberation] that transforms an individual's act or conduct into a crime

Judgment, If 4 (Int'l Crim. Trib. for Bangladesh Aug. 10, 2016); Prosecutor v. Sardar, Case No. 06 of 2015, Judgment, If 4 (Int'l Crim. Trib. for Bangladesh Dec. 5, 2016). See also Prosecutor v. Prodhan, ICT-BD o1 of 2016, Judgment, ๆๆ 635, 639-40 (Int'l Crim. Trib. for Bangladesh Apr. 19, 2017).

23 Prosecutor v. Miah, Case No. 03 of 2016, Judgment, ๆ 8 (Int'l Crim. Trib. for Bangladesh Nov. 2017); Prosecutor v. Tarafdar, Case No. o6 of 2016, Judgment, If 9 (Int'l Crim. Trib. for Bangladesh Jan. 10 2018); Prosecutor v. Ahmed, Case No. o5 of 2015, Judgment, I 9 (Int'l Crim. Trib. for Bangladesh Mar. 13 2018); Prosecutor v. Fakir, Case No. 04 of 2016, Judgment, \ 9 (Int'l Crim. Trib. for Bangladesh May 10, 2018); Prosecutor v. Talukder, Case No. o8 of 2016, Judgment, I 9 (Int'l Crim. Trib. for Bangladesh July 17, 2018); Prosecutor v. Shikder, Case No. 10 of 2016, Judgment, ๆ 10, 12 (Int'l Crim. Trib. for Bangladesh Aug. 13, 2018); Prosecutor v. Ali, Case No. 05 of 2016, Judgment, ๆ 9 (Int'l Crim. Trib. for Bangladesh Nov. 5, 2018); Prosecutor v. Majid, Case No. o7 of 2016, Judgment, ๆ 10 (Int'l Crim. Trib. for Bangladesh Mar. 28, 2019); Prosecutor v. Hidaetulla, Case No. o1 of 2017, Judgment, I 9 (Int'l Crim. Trib. for Bangladesh Apr. 24, 2019); Prosecutor v. Rahman, Case No. o1 of 2018, Judgment, ๆ 12 (Int'l Crim. Trib. for Bangladesh June 27, 2019); Prosecutor v. Samad, Case No. 04 of 2018, Judgment, ๆ ๆ 7, 9 (Int'l Crim. Trib. for Bangladesh Aug. 27, 2019); Prosecutor v. Mondol, Case No. 02 of 2017, Judgment, ๆ 9 (Int'l Crim. Trib. for Bangladesh Oct. 15, 2019); Prosecutor v. Sattar, Case No. 05 of 2018, Judgment, ๆ 198 (Int'l Crim. Trib. for Bangladesh Dec. 11, 2019). 
against humanity". ${ }^{24}$ The ICT-2 considered the armed conflict not only as a factual background but also as a legal context. The Appellate Division of the Bangladesh Supreme Court had once discussed the origin of crimes against humanity but did not analyse the nexus issue in detail. ${ }^{25}$

As observed above, the 1973 Act provides no answer to the question of whether crimes against humanity require a nexus with an armed conflict. Case law of the ICTs also did not assist in understanding the nexus issue. Judgments of the ICT-1 did not clarify but confused the nexus issue. The 1973 Act and the two ICTs' practice, therefore, are less valuable in clarifying the nexus issue. The following parts turn to other authorities and jurisprudence of international tribunals.

\section{The Nexus with an Armed Conflict for Crimes against Humanity in Customary Law}

After World War II, there were various definitions of crimes against humanity as international crimes. ${ }^{26}$ Scholars' opinions also differ on whether a nexus

24 See Prosecutor v. Alim, Case No. o1 of 2012, Judgment, \ 118 (Int'l Crim. Trib. for Bangladesh Oct. 9, 2013); See also Prosecutor v. Azad, Case No. 05 of 2012, Judgment, ๆ 78 (Int'l Crim. Trib. for Bangladesh 21 Jan. 2013); Prosecutor v. Molla, Case No. o2 of 2012, Judgment, ๆ 79 (Int'l Crim. Trib. for Bangladesh Feb. 5, 2013); Prosecutor v. Kamaruzzaman, Case No. 03 of 2012, Judgment, ๆ 133 (Int'l Crim. Trib. for Bangladesh May 9, 2013); Prosecutor v. Mujahid, Case No. 04 of 2012, Judgment, ๆ 123 (Int'l Crim. Trib. for Bangladesh July, 17 2013); Prosecutor v. Uddin, Case No. ol of 2013, Judgment, ๆ 405 (Int'l Crim. Trib. for Bangladesh Nov. 3, 2013); Prosecutor v. Ali, Case No. 03 of 2013, Judgment, \ 109 (Int'l Crim. Trib. for Bangladesh Nov. 2, 2014); Prosecutor v. Qaiser, Case No. 04 of 2013, Judgment, ๆף 925, 930 (Int'l Crim. Trib. for Bangladesh Dec. 23, 2014); Prosecutor v. Sobhan, Case No. o1 of 2014, Judgment, ๆ ๆ 532, 539 (Int'l Crim. Trib. for Bangladesh Feb. 18, 2015); Prosecutor v. Rahman, Case No. 02 of 2014, Judgment, ๆ ๆ 5, 30, 262 (Int'l Crim. Trib. for Bangladesh May 20, 2015); Prosecutor v. Mallik, Case No. o3 of 2014, Judgment, ๆ ๆ 93, 273 (Int'l Crim. Trib. for Bangladesh July 16, 2015).

25 See Mollah v. Government of Bangladesh, Case No. 24-25 of 2013, Judgment, ๆ ๆ 152-58 (Supreme Court of Bangladesh Sept. 17, 2013).

26 See Charter of the International Military Tribunal art. 6(c), opened for signature Aug. 8, 1945, 59 Stat. 1544, 82 U.N.T.S. 279 (entered into force Aug. 8, 1945) [hereinafter Nuremberg Charter]; International Military Tribunal for the Far East Charter art. 5(c), opened for signature Jan. 19, 1946, T.I.A.S. 1589; Allied Control Council Law No. 10 art. II(1)(a), Dec. 20, 1945; Statute of the International Criminal Tribunal for the Former Yugoslavia art. 5, May 25, 1993 (amended 2002); Statute of the International Criminal Tribunal for Rwanda art. 3, Nov. 8, 1994 (amended 2006); Rome Statute of the International Criminal Court art. 7, opened for signature July 17, 1998, 2187 U.N.T.S. 3 (entered into force July 1, 
with an armed conflict is a legal requirement for this crime. This section mainly addresses the notion of crimes against humanity and the existence of a nexus with an armed conflict as a legal element for crimes against humanity from an historical perspective.

\subsection{The Notions of Crimes against Humanity in International Law}

Definitions of crimes against humanity are different concerning the issue of the nexus with an armed conflict. According to the Nuremberg and Tokyo Charters as well as the 1950 International Law Commission (ILC) Nuremberg Principles, a nexus with an armed conflict was a legal requirement. By contrast, this nexus was omitted in the 1945 Control Council Law No. 10 and was abandoned in the 1998 Rome Statute of the International Criminal Court (Rome Statute). Article 5 of the Statute of the International Criminal Tribunal for the former Yugoslavia (ICTY), 1993 also explicitly referred to a link with an armed conflict; however, Article 3 of the Statute of the International Criminal Tribunal for Rwanda (ICTR), 1994 did not refer to armed conflict despite all offences being committed in the context of a civil war. The 1950, 1991, and 1996 versions of the Draft Code of Offences (Crimes) do not refer to a connection with an armed conflict. ${ }^{27}$

These definitions show a lack of uniformity of the text of crimes against humanity. The existence of different definitions would not inherently undermine the claim that there is a consensus on crimes against humanity as an

2002) (amended 2010) [hereinafter Rome Statute]; Statute of the Special Court for Sierra Leone art. 6(1), Jan. 16, 2002; Law on the Establishment of the Extraordinary Chambers in the Courts of Cambodia for the Prosecution of Crimes Committed During the Period of Democratic Kampuchea art. 5, Oct. 27, 2004; Statute of the Iraqi Special Tribunal art. 12, 43 I.L.M. 231 (2004); Regulation No. 2000/15 on the Establishment of Panels with Exclusive Jurisdiction over Serious Criminal Offences $\S 5$, June 6, 20oo; Statute of the Extraordinary African Chambers within the Courts of Senegal Created to Prosecute International Crimes Committed in Chad between 7 June 1982 and 1 December 1990 arts. 4(b), 6, Jan. 30, 2013, 52 I.L.M. 1028 (2013).

27 In fact, the 1950 and 1991 drafts of the ILC's Draft Code of Offences (Crimes) avoided using the term "crimes against humanity". See Text of a Draft Code of Offences against the Peace and Security of Mankind suggested as a Working Paper for the International Law Commission, [1950] 2 Yearbook of the International Law Commission 277, U.N. Doc. A/CN.4/SER.A/195o/Add.1; Report of the International Law Commission on the work of its forty-third session, 46 U.N. GAOR Supp. No. 10, \176, U.N. Doc A/46/10 (1991), reprinted in [1991] 2 Yearbook of the International LaW Commission 96, U.N. Doc. A/CN.4/SER.A/1991/Add.1 (Part 2) (Article 21. Systematic or mass violations of human rights); Draft Code of Crimes against the Peace and Security of Mankind, ${ }_{51}$ U.N. GAOR Supp. No. 10, ๆ 5o, U.N. Doc A/51/10 (1996), reprinted in [1996] 2 YeARbook OF THE International LaW Commission 47, U.N. Doc. A/CN.4/SER.A/1996/Add.1 (Part 2). 
international crime under customary law. However, the various definitions indicate different understandings of nexus element of these crimes in customary law. These understandings are related to the issue of what makes an inhumane act a crime against humanity. Competing views exist in academia on this question. ${ }^{28}$ One viewpoint is that, from a historically descriptive perspective, most of the crimes were planned and committed by State actors, who are generally not the physical perpetrators who committed the crimes. It is likely that they would go unpunished without the availability of international jurisdiction. ${ }^{29}$ After examining the establishment of the International Military Tribunal (IMT) in Nuremberg and the International Military Tribunal of Far East (IMTFE) in Tokyo and the historic experience of mass crimes in Cambodia, in the former Yugoslavia, and in Rwanda, Judge Kaul of the International Criminal Court (ICC) concluded that "historic origins are decisive in understanding the specific nature and fundamental rationale of the category of international crime". ${ }^{30} \mathrm{He}$ added that "a demarcation line must be drawn between international crimes and human rights infractions; between international crimes and ordinary crimes; between those crimes subject to international jurisdiction and those punishable under domestic penal legislation".31 The historical experience is vital to understanding what the fundamental rationale of crimes against humanity is and how the nexus element of the crimes against humanity has come and changed.

\subsection{A Nexus with an Armed Conflict: Two Theories}

Currently, it is generally agreed that the notion of crimes against humanity does not require a nexus with an armed conflict. To date, national legislation of almost 6o States, including the UK, the US, Canada, Germany, Australia, New Zealand, the Philippines, and Vietnam as well as some African States, do not

28 Margaret M. deGuzman, Crimes Against Humanity, in Routledge Handbook Of International Criminal LaW 121-38 (W.A. Schabas \& N. Bernaz eds., 2011); KaI Ambos, Treatise on International Criminal Law: Volume 1: Foundations AND General Part 55-56 (2013); Situation in the Republic of Kenya, ICC-o1/o9, Decision Pursuant to Article 15 of the Rome Statute on the Authorization of an Investigation into the Situation in the Republic of Kenya, at 29 n. 62 (Mar. 31, 2010).

29 As thoroughly demonstrated by Margaret deGuzman, there are four approaches, and each approach has its merits and flaws to some extent. None of the four approaches could provide an entirely rational argument as regards every specific issue. See deGuzman, supra note 28 .

30 Situation in the Republic of Kenya, ICC-o1/og, Dissenting Opinion of Judge Hans-Peter Kaul, ๆ ๆ 58-65 (Mar. 31, 2010), https://www.icc-cpi.int/CourtRecords/CR2010_02409.pdf. Id. $₫ 65$. 
require a link with an armed conflict for crimes against humanity. ${ }^{32}$ The ILC also endorsed the view of no nexus with an armed conflict in its recent draft convention on crimes against humanity. ${ }^{33}$ However, scholars' opinions differ with respect to a nexus with an armed conflict as a legal element for crimes against humanity in the past and the disappearance of such a nexus.

Two theories exist about this issue. The Steady State theory argues that the link with an armed conflict was never a legal but a jurisdictional requirement since the 1945 IMT in Nuremberg. Thus, it is not necessary to discuss when this link has disappeared as it never existed. The Big Bang theory claims that the nexus with an armed conflict was a legal requirement before the IMT, while it disappeared at some time. If the Big Bang theory is justified, a further question is whether that link has disappeared under customary law before the material time in 1971.

According to Article 6(c) of the Nuremberg Charter, the definition of crimes against humanity was linked to "any crime within the jurisdiction of the Tribunal". ${ }^{34}$ It is understood that the phrase "any crime within the jurisdiction of the Tribunal" refers to crimes against peace and war crimes. ${ }^{35}$ In practice, ill-treatment and murder of non-German civilians in concentration camps committed by Germans during the war were charged mostly as both crimes against humanity and war crimes. ${ }^{36}$ In addition, as Robert Jackson addressed at the London International Conference on Military Trials (London Conference) in 1945:

The reason that this program of extermination of Jews and destruction of the rights of minorities becomes an international concern is this: it was a part of a plan for making an illegal war. Unless we have a war connection

32 Penal Code art. 342 (Viet.); ICC, National Implementing Legislation DataBASE, https://iccdb.hrlc.net/data/.

33 Int'l Law Comm'n, Rep. on the Work of Its Sixty-Ninth Session, U.N. Doc. A/72/10, at 25-28 (2017); Int'l Law Comm'n, Rep. on the Work of Its Sixty-Seventh Session, U.N. Doc. $\mathrm{A} / 70 / 10$, at 59 (2015).

34 Nuremberg Charter, supra note 26, art. 6(c).

35 U.N. Secretary-General, The Charter and Judgment of the Nürnberg Tribunal - History and Analysis: Memorandum submitted by the Secretary-General, at 68-69, U.N. Doc. A/CN.4/5 (Mar. 3, 1949).

36 Nuremberg Military Tribunal, The Flick CASe, reprinted in 6 Trials of WAR Criminals Before The Nuremberg Military Tribunals (TWC) 1, 1187-212 (1952) [hereinafter The Flick Case]; Nuremberg Military Tribunal, The Hostage Case, reprinted in 11 TWC 757 (1950); U.N. WAR Crimes Comm'N, The ZyKLON B CASE, reprinted in 1 LaW Reports of Trials of War Criminals (LRTWC) 93 (1947); U.N. War Crimes COMm'N, THE BELSEN CASE, reprinted in 2 LRTWC 1 (1947). 
as a basis for reaching them, I would think we have no basis for dealing with atrocities. They were a part of the preparation for war or for the conduct of the war in so far as they occurred inside of Germany and that makes them our concern. ${ }^{37}$

Indeed, Streicher and von Schirach were found guilty only of crimes against humanity by the гмт. But the гмт judgment also established that the two defendants' conducts were associated with war crimes committed by others. ${ }^{38}$ Thus, Article 6(c) of the Nuremberg Charter required a link with crimes against peace or war crimes.

One may note that the reference to the phrase "before or during the war" in Article 6(c) of the Nuremberg Charter permits prosecutions of crimes against humanity before the war. ${ }^{39}$ The IMT in some specific instances also referred to some acts before the war. Nevertheless, the IMT in practice only considered atrocities committed "during the war" in connection with the aggressive wars as crimes against humanity. ${ }^{40}$ For example, von Schirach was largely found guilty of crimes against humanity for acts after the beginning of the war, which were in connection with Austria's occupation. ${ }^{41}$ According to the IMT, " $[\mathrm{t}] \mathrm{o}$ constitute Crimes against Humanity, the acts relied on before the outbreak of war must have been in execution of, or in connection with, any crime within the jurisdiction of the Tribunal". ${ }^{42}$ In addition, the IMT also held that since many actions committed before the war were not proved in connection with

37 Minutes of Conference Session (July 23, 1945), in Report of Robert H. Jackson United States Representative to the International Conference on Military Trials: LoNdON, 1945, 331 (1949).

38 Nuremberg Int'l Military Tribunal, The International Military Tribunal [France V. Göring], reprinted in I Trial of the Major War Criminals before the International Military Tribunal (TMWC) 171, 302-04, 318-20 (1947) [hereinafter France v. Göring].

39 Egon Schwelb, Crimes Against Humanity, 23 British Yearbook of International LAW 178, 188, 193-95, 204 (1946).

40 France v. Göring, supra note 38, at 254; The Flick Case, supra note 36, at 1212; Anatole Goldstein, Crimes Against Humanity: Some Jewish Aspects, 1 Jewish Yearbook of INTERNATIONAL LAW 206, 221 (1948).

41 France v. Göring, supra note 38, at 302-04, 318-20; Schwelb, supra note 39, at 205; see Nuremberg Int'l Military Tribunal, The International Military TriBUNAL, reprinted in 22 TMWC 1, 549 (1948), https://www.loc.gov/rr/frd/Military_Law/ pdf/NT_Vol-XXII.pdf (noting that "Streicher's incitement to murder and extermination at the time when Jews in the East were being killed under the most horrible conditions clearly constitutes persecution on political and racial grounds in connection with War Crimes, as defined by the Charter, and constitutes a Crime against Humanity").

France v. Göring, supra note 38, at 254. 
any crime, it could not "make a general declaration that the acts before 1939 were crimes against humanity within the meaning of the Charter".43 In the IMT, the essence of the linkage with war crimes or crimes against peace, in fact, was a connection with aggressive wars. ${ }^{44}$ Therefore, it was potentially possible for the Iмт to prosecute crimes against humanity before the war, but only if a nexus existed between the acts and aggressive wars. ${ }^{45}$ These observations indicate that acts committed in peacetime without any connection to the subsequent wars would not constitute crimes against humanity at that time. Only concrete acts committed in connection with an armed conflict would constitute crimes against humanity, regardless of whether they occurred before or during the war.

Nevertheless, some commentators consider that the nexus with aggressive wars was intentionally inserted by the Four Powers to limit the jurisdiction of the Iмт over individuals of Axis countries. ${ }^{46}$ Egon Schwelb and Roger Clark argued that the armed conflict linkage requirement in the Nuremberg Charter was a jurisdictional limit rather than an inherent substantive element of crimes against humanity. ${ }^{47}$ In addition, the definition of crimes against humanity in the Nuremberg Charter was almost replicated in Article 5(c) of the Tokyo Charter. According to the former Judge Röling of the IMTFE, "the connection did not restrict the scope of the crime, but only the scope of [the court's] jurisdiction". ${ }^{48}$ Furthermore, the US and the Extraordinary Chambers in the Courts of Cambodia (ECCC) also once argued that the nexus never existed. By citing the work of the UN War Crimes Commission, the US delegation in 1996 stated that " $[t]$ he record of the development of the Nuremberg and Tokyo Charters does not [...] indicate that the drafters believed that the nexus was required as a matter of law".49 A Chamber of the ECCC in the Duch

43 Id.; Goldstein, supra note 40.

44 Schwelb, supra note 39, at 204; Yoram Dinstein, Case Analysis: Crimes Against Humanity After Tadić, 13 Leiden Journal of International LaW 373, 383-84 (2000).

45 Int'l Law Comm'n, Rep. on the Work of Its Second Session, U.N. Doc. A/1316, ๆ 122 (1950).

46 Roger S. Clark, History of Efforts to Codify Crimes against Humanity, in Forging A Convention for Crimes against Humanity 11 (Leila Nadya Sadat ed., 2010); United States Delegation, Crimes against Humanity, Lack of a Requirement for a Nexus to Armed Conflict (ICC Preparatory Works, Mar. 25, 1996), available at https://www.legal -tools.org/doc/1163fc/pdf/.

47 Clark, supra note 46; Schwelb, supra note 39 , at 188, 194-95.

48 Antonio Cassese \& B.V.A. Röling, The Tokyo Trial and Beyond: Reflections of a Peacemonger 56 (1993).

49 United States Delegation, supra note 46, at 2, n. 4. 
case referred to the ICTY's Tadic Appeals Chamber decision on jurisdiction to justify an argument that a nexus never existed. ${ }^{50}$

Clark first pointed out that in Article II of the 1948 Convention on the Prevention and Punishment of the Crime of Genocide, a nexus with aggressive wars was not required for the crime of genocide, which is closely related to the persecution type of crimes against humanity in the Nuremberg Charter. ${ }^{51}$ In addition, he noted that the connection to the "initiation of war and war crimes" was omitted in Control Council Law No. 10. Last, Clark clarified that in the original English and French texts of Article 6(c) of the Nuremberg Charter adopted in August 1945, a semi-colon existed between "before or during the war" and "or persecutions". However, in the original Russian text, a comma was used. ${ }^{52}$ This semi-colon in the English and French texts was later amended to a comma in the "Semi-colon Protocol" in October $1945 .{ }^{53}$ Given the modification of this semi-colon, Clark concluded that the phrase "in execution of or in connection with any crime within the jurisdiction of the Tribunal" was only a requirement for persecutions. ${ }^{54}$ With regard to crimes against humanity, acts of "murder, extermination, enslavement, deportation, and other inhumane acts committed against any civilian population" are not required to be linked with the war. ${ }^{55}$ As for acts of persecution, the "crimes" mentioned in the phrase "in connection with any crime" refer to the murder type of underlying offences, such as "murder, extermination or enslavement", instead of "crimes against peace" and "war crimes" or aggressive wars. ${ }^{56}$ In his view, a link with these underlying offences is confirmed by the Rome Statute, which requires

50 Prosecutor v. Kaing Guek Eav alias Duch, Case No. o01/18-07-2007/ECCC/TC, Judgment, If 292 (Extraordinary Chambers in the Courts of Cambodia July 26, 2010) (Cambodia). Clark, supra note 46, at 12; Roger S. Clark, Crimes Against Humanity at Nuremberg, in The Nuremberg Trial and International LaW 19o-92 (George Ginsburgs \& V.N. Kudrîavtsev eds., 1990).

See Nuremberg Charter, supra note 26 ("Crimes against humanity[:] namely, murder, extermination, enslavement, deportation, and other inhumane acts committed against any civilian population, before or during the war, or persecutions on political, racial or religious grounds in execution of or in connection with any crime within the jurisdiction of the Tribunal, whether or not in violation of the domestic law of the country where perpetrated"); see also Clark, supra note 46 , at 11.

Protocol to Agreement and Charter (Oct. 6, 1945), in Report of Robert H. JaCkson United States Representative to the International Conference on Military Trials: London, 1945, 429 (1949) (protocol rectifying discrepancy in the text of the Charter, drawn up by the Governments that concluded the Agreement of August 8, 1945).

$54 \quad$ Nuremberg Charter, supra note 26.

$55 \quad I d$.

$56 \quad I d$. 
persecution to be "in connection with any act referred to in this paragraph". ${ }^{57}$ Accordingly, Clark argued that the Nuremberg Charter did not acknowledge a substantive link with aggressive wars or an armed conflict for crimes against humanity in international law. ${ }^{58}$

A different argument, however, is also tenable by reference to these same sources. ${ }^{59}$ It is argued that the nexus with an armed conflict in the Nuremberg Charter was a substantive legal element rather than a jurisdictional limit for the following reasons. Firstly, it is the wording "trial and punishment of the major war criminals of the European Axis" in Article 1 and in the chapeau of Article 6 of the Nuremberg Charter, rather than the nexus with war, that was inserted to limit the jurisdiction of the Iмт. ${ }^{60}$ Secondly, the semi-colon in the English and French texts has not been found in preceding drafts and where it came from is a puzzle. The Semi-colon Protocol amended the semi-colon two months later. This slight revision has a high impact on the definition of crimes against humanity, which required all prohibited murder-type acts to be linked to war. It is not persuasive to argue that the reviewers changed it mistakenly and failed to consider the impact of the revision. Thirdly, persecution as a crime against humanity requires a link with the underlying murder-type acts. Such a link for persecution does not exclusively exclude an alternative requirement of a link with any crime within the jurisdiction of the ICC (war crimes, genocide, and aggression). This link builds a relationship between murder type offences and persecution type offences. But the link between the two types of offences cannot justify the view that the concept of crimes against humanity in the Nuremberg Charter substantively required no link with war.

Fourthly, the US delegation might have mixed "the context" of war or peace with "the nexus" with aggressive wars. ${ }^{61}$ The Legal Committee of the UN War Crimes Commission once declared that "[i]t was irrelevant whether a crime against humanity had been committed before or during the war". ${ }^{2}$ By referring to the Nuremberg and Tokyo Charters, ${ }^{63}$ the UN War Crimes Commission confirmed this clarification. ${ }^{64}$ Nevertheless, the Legal Committee concluded that "the inhumane acts committed against any civilian population before the war

\footnotetext{
$57 \quad$ Rome Statute, supra note 26 , art. $7(1)(\mathrm{h})$.

$5^{8}$ Clark, supra note 46 , at 11.

59 Schwelb, supra note 39, at 195.

6o Nuremberg Charter, supra note 26.

61 United States Delegation, supra note 46, at 1, 4.

62 U.N. War Crimes Comm'n, History of the United Nations War Crimes Commission and the Development of the LaWs of WaR 178-79 (1948).

$63 I d$. at $522-24$.

64 Id. at $192-93$.
} 
[...] fall under crimes against humanity" because the purpose of these clashes was in connection with the contemplated invasion of Czechoslovakia. ${ }^{65}$ Thus, acts committed before the war (in peacetime) would be considered as crimes against humanity only if these acts were connected with the later aggressions of war. In fact, the ILC in its 1950 Nuremberg Principles deleted the phrase "before or during the war" in defining crimes against humanity, while it specifically referred to the connection with war crimes and aggressive wars. In its commentary to Principle VI(c), the ILC emphasised that crimes against humanity "need not be committed during a war", but it maintained that "such crimes may take place also before a war in [connection] with crimes against peace".66 This is the correct reading of the Nuremberg Charter and the IMT judgment. ${ }^{67}$ On the other hand, the text of Control Council Law No. 10 did not refer to the nexus with war. ${ }^{68}$ In practice, except for the Justice and the Einsatzgruppen cases, subsequent tribunals applying that law required a connection with the aggressive wars for acts committed before and during the war. ${ }^{69}$ Suspects in the Flick and Ministries cases were charged with crimes against humanity committed in peacetime..$^{70}$ However, the tribunals in the two cases held that it would not contemplate offences committed before the war and having no connection with the war. ${ }^{71}$ As shown above, the fact that crimes against humanity might be committed before the war does not indicate that the nexus with aggressive wars was not required. The US delegation went too far to argue that there was no nexus with an armed conflict in the Nuremberg Charter. ${ }^{72}$

65 Id. at $178-79$.

66 U.N. Doc. A/1316, supra note 45, ๆ 123.

67 Dinstein, supra note 44 , at 384.

68 Nuremberg Military Tribunal, The Justice Case, reprinted in 3 TWC 1, 972-73 (1951); Nuremberg Military Tribunal, The Einsatzgruppen CASe, reprinted in 4 TWC 1, 499 (1950).

69 The Flick Case, supra note 36, at 1212-13; Nuremberg Military Tribunal, The Krupp CASE, reprinted in 9 TwC 1 (1948); Nuremberg Military Tribunal, The Pohl CASE, reprinted in 5 TWC 193, 991-92 (1950); Nuremberg Military Tribunal, The Ministries Case, reprinted in 13 twC 1 (1952); see also Kevin J. Heller, The Nuremberg Military Tribunals AND THE ORIGINS OF INTERNATIONAL CRIMINAL LAW 236-42 (2011).

70 U.S. v. Flick, Case No. 5, Indictment, If 13 (Nuremberg Mil. Trib. 1947), https://digital commons.law.uga.edu/cgi/viewcontent.cgi?article $=1000 \&$ context=nmt5; U.S. v. The Ministries, Case No. 11, Indictment, I 30 (Nuremberg Mil. Trib. 1947), https://digitalcommons.law.uga.edu/cgi/viewcontent.cgi?article $=1000 \&$ context=nmt11.

71 The Flick Case, supra note 36, at 1212; The Ministries Case, supra note 69, at 116; Nuremberg Military Tribunal, The Ministries Case, reprinted in 14 TWC 1, 557 (1952); HELLER, supra note 69, at 236-42.

72 William A. Schabas, The International Criminal Court: A Commentary on THe Rome Statute 170 (2nd ed. 2016). 
Fifthly, the Tadic Appeals Chamber of the ICTY, in fact, supported a reading that a nexus with an armed conflict was a legal requirement in the Nuremberg Charter. Article 5 of the ICTY Statute provides a notion of crimes against humanity committed in "armed conflict". ${ }^{73}$ In the Tadic Appeals Chamber decision on jurisdiction, the Chamber held that:

$[\mathrm{T}]$ he nexus between crimes against humanity and either crimes against peace or war crimes, required by the Nuremberg Charter, was peculiar to the jurisdiction of the Nuremberg Tribunal. Although the nexus requirement in the Nuremberg Charter was carried over to the 1948 General Assembly resolution affirming the Nuremberg principles, there is no logical or legal basis for this requirement and it has been abandoned in subsequent State practice with respect to crimes against humanity. Most notably, the nexus requirement was eliminated from the definition of crimes against humanity contained in Article II(1)(c) of Control Council Law No. 10 of 20 December $1945 .{ }^{74}$

It is by now a settled rule of customary international law that crimes against humanity do not require a connection to international armed conflict.... [C] ustomary international law may not require a connection between crimes against humanity and any conflict at all.... [T] he Security Council may have defined the crime in Article 5 more narrowly than necessary under customary international law. ${ }^{75}$

The literal meaning of the first paragraph is a bit ambiguous. By referring to "peculiar to the jurisdiction of the Nuremberg Tribunal", the Chamber seems to imply that a nexus with an armed conflict for crimes against humanity was not a substantive but a jurisdictional requirement in the Iмт. ${ }^{76}$ At the same time, the Appeals Chamber said that the nexus requirement had been "abandoned in subsequent state practice" and referred to Control Council Law No. 10 to indicate that the notion of crimes against humanity began to change on

73 ICTY Statute art. 5 states that the Tribunal "shall have the power to prosecute persons responsible for the following crimes when committed in armed conflict, whether international or internal in character, and directed against any civilian population".

74 Prosecutor v. Tadić, Case No. IT-94-1, ๆ 140.

$75 I d$. I 141; For an analysis of the case concerning the nexus requirement, see Dinstein, supra note 44 , at $386-87$.

76 Prosecutor v. Tadić, Case No. IT-94-1, ๆ 140. 
20 December $1945 .{ }^{77}$ If the nexus with an armed conflict was not a substantive requirement, how could it be "abandoned in subsequent State practice"? 78

In the second paragraph cited above, with reference to "[no] connection to international armed conflict" as "a settled" customary rule, on the one hand, the Appeals Chamber held that the nexus with an armed conflict was expanded to include a nexus with non-international armed conflict. ${ }^{79}$ On the other hand, the Appeals Chamber held that the text of crimes against humanity with a nexus in Article 5 of the ICTY Statute was narrower than what customary law required. The Appeals Chamber acknowledged that a nexus requirement existed, but it said it was "obsolescent". ${ }^{80}$ There is a cross-reference to the two paragraphs cited, confirming the relationship between them. The Appeals Chamber stated that "customary international law no longer requires any nexus between crimes against humanity and armed conflict [...] Article 5 was intended to reintroduce this nexus for the purposes of this Tribunal". ${ }^{81}$ The expressions of "no longer" and of "reintroduce" further discredit the idea that a nexus with an armed conflict was never a requirement. The clarification of the Tadić Appeals Chamber decision demonstrates that a link with an armed conflict was a legal element. This clarification also indicates that the chamber of the ECCC in Duch misunderstood the Tadić case. Therefore, the EccC decision in Duch is also less valuable on the interpretation of the nexus issue.

As the Secretary-General summarised, the nexus with war is a compromise between two ideas. ${ }^{82}$ One is the traditional principle that the treatment of nationals is a matter of domestic jurisdiction. The competing principle is that inhumane treatment of human beings is wrong even if it is tolerated or practised by their States, in peace and war, and that this wrong should be penalised in the interest of the international community. Without abandoning the traditional principle, the latter idea of guaranteeing a minimum standard of fundamental rights to all human beings was qualified by the nexus requirement at that time. ${ }^{83}$ In other words, since aggressive wars affect the rights of other States, the nexus with an armed conflict justifies international prosecution. A construction of no nexus at that time means that acts of their governmental leaders against their citizens in peacetime might be charged

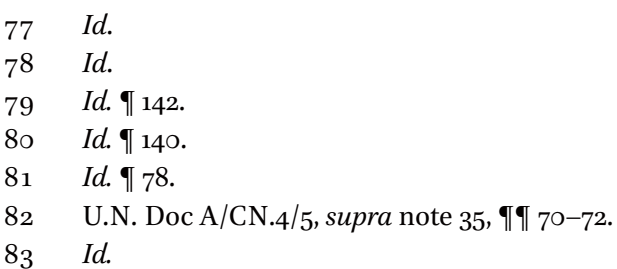


with crimes against humanity. It would be going too far to conclude that States aimed to create the notion of crimes against humanity without any association with war.

The Four Powers knew that they were creating a new regime that would be binding on all States in the future. The American delegate Jackson stated that:

If certain acts and violations of treaties are crimes, they are crimes whether the United States does them or whether Germany does them, and we are not prepared to lay down a rule of criminal conduct against others which we would not be willing to have invoked against us. ${ }^{84}[\ldots]$ $[O]$ rdinarily we do not consider that the acts of a government toward its own citizens warrant our interference. We have some regrettable circumstances at times in our own country in which minorities are unfairly treated. We think it is justifiable that we interfere or attempt to bring retribution to individuals or to states only because the concentration camps and the deportations were in pursuance of a common plan or enterprise of making an unjust or illegal war in which we became involved. We see no other basis on which we are justified in reaching the atrocities which were committed inside Germany, under German law, or even in violation of German law, by authorities of the German state. ${ }^{85}$

These statements demonstrate that without a link with aggressive wars, the leaders of those countries that created the IMT might be at a real risk for murder or persecution of their own civilian populations. The UK Chief Prosecutor Hartley Shawcross shared this view of the nexus with war. The prosecutor believed that acts, not associated with aggressive wars and committed by a government against their civilian populations, should not constitute crimes against humanity as a distinct international crime. ${ }^{86}$

A short survey of the drafting history of Article 7 of the 1998 Rome Statute is also helpful in clarifying the nexus issue. The Ad Hoc Committee in 1995 reported that "in light of Nuremberg precedent and the two UN ad hoc tribunals, there were different views as to whether crimes against humanity

$84 \quad$ Minutes of Conference Session, supra note 37 , at 33 .

85 Id. at 333 .

86 Nuremberg Int'l Military Tribunal, One Hundred and Eighty-seventh Day: Afternoon Session, reprinted in 19 TMWC 433, 470-71 (1948) (Sir Hartley Shawcross making Final Speech on behalf of Prosecution). In his view, "the Charter merely develops a pre-existing principle" and the crimes against humanity in the jurisdiction of the Iмт "are limited to this extent-they must be crimes the commission of which was in some way connected with, in anticipation of or in furtherance of the crimes against the peace or the war crimes stricto sensu with which the defendants are indicted". 
could be committed in peace time". ${ }^{87}$ Australia said that there is no longer any requirement of such a nexus between an armed conflict and crimes against humanity in customary law. ${ }^{88}$ In the Preparatory Committee, there were debates about the nexus with an armed conflict. ${ }^{89}$ It was generally agreed that the crime need not be limited to acts during international armed conflict. ${ }^{90}$ The US strongly argued for removing a nexus with an armed conflict. ${ }^{91}$ By contrast, China and Russia argued for retaining the nexus with an armed conflict. ${ }^{92}$ There were proposals to incorporate the wording "in time of peace or in time of war" in the chapeau of the provision about crimes against humanity. This proposal, however, did not survive in the 1998 Draft Statute adopted by the Preparatory Committee. ${ }^{93}$ In the Draft Statute, one alternative of the definition of crimes against humanity retains the phrase "in armed conflict" in a bracket. ${ }^{94}$ At the 1998 Rome Conference, the majority of States supported the

87 Rep. of the Ad Hoc Comm. on the Establishment of an Int'l Crim. Ct., 5o U.N. GAOR Supp. No. 22, at 79, U.N. Doc. A/5o/22 (Sept. 6, 1995); Press Release, General Assembly, Sixth Committee Hears Differing Views on Code of Crimes Against International Peace and Security, U.N. Press Release GA/L/2866 (Oct. 16, 1995) (Argentina supported crimes against humanity in peacetime; while India opposed this idea); Summary of Interventions by the Australian Delegation on the Specification of Crimes (Aug. 17, 1995).

88 Summary of Interventions by the Australian Delegation on the Specification of Crimes (Aug. 17, 1995).

89 Rep. of the Preparatory Comm. on the Establishment of an Int'l Crim. Ct., $5^{1}$ U.N. GAOR Supp. No. 22, ๆ ๆ 88-9o, U.N. Doc. A/51/22 (Vol. I) (Sept. 13, 1996); Press Release, Preparatory Committee on International Criminal Court Concludes First Session, U.N. Press Release L/2787 (Apr. 12, 1996). For States supporting no armed conflict nexus, see Press Release, Preparatory Committee on Establishment of International Criminal Court Begins First Session, U.N. Press Release L/2761 (Mar. 25, 1996) (Australia \& the Netherlands); Japan, "Proposal by Japan on Crimes against Humanity" (Mar. 25, 1996); the UK, "Proposal by the United Kingdom on Crimes against Humanity: Article 20 quarter" (Mar. 25, 1996); The Netherlands, "Crimes Against Humanity" (Mar., 1996); Denmark, "Crime Against Humanity: Chapeau and residual clause" (Mar. 27, 1996).

9o Press Release, Preparatory Committee for Establishment of International Criminal Court Discusses Definitions of 'Genocide', 'Crimes Against Humanity', U.N. Press Release L/2762 (Mar. 25, 1996).

91 United States Delegation, supra note 46.

92 Press Release, 'Crimes Against Humanity' Must be Precisely Defined Say Speakers in Preparatory Committee for International Court, U.N. Press Release L/2763.Rev.1* (Mar. 26, 1996).

93 Rep. of the Preparatory Comm. on the Establishment of an Int'l Crim. Ct., $5_{1}$ U.N. GAOR Supp. No. 22A, at 66, U.N. Doc. A/51/22 (Vol. II) (Sept. 13, 1996).

94 U.N. Diplomatic Conference of Plenipotentiaries on the Establishment of an International Criminal Court, Draft Statute for the International Criminal Court, at 20-21, U.N. Doc. A/ CONF.183/2/Add.1 (Apr. 14, 1998); For a detailed analysis of the Preparatory Committee's drafts, see SCHABAS, supra note 72 , at 170. 
view that crimes against humanity can be committed both in wartime and in peacetime..$^{95} \mathrm{~A}$ large number of States expressed their satisfaction with the omission of an armed conflict. ${ }^{96}$ States widely accepted the absence of the nexus with an armed conflict at the Rome Conference. The drafting history also indirectly support the Big Bang theory that a nexus was required, at the very least, in the гмт. ${ }^{97}$

As shown above, the nexus with aggressive wars was required for crimes against humanity in the Nuremberg Charter and IMT. This nexus was not a jurisdictional link but a substantive element of crimes against humanity. ${ }^{98}$ The

95 U.N. Conference of Plenipotentiaries on the Establishment of an International Criminal Court, ๆף 6-7, U.N. Doc. A/CONF.183/SR.1 (Nov. 20, 1998) (Italy); U.N. Conference of Plenipotentiaries on the Establishment of an International Criminal Court, \ 62, U.N. Doc. A/CONF.183/SR.8 (June 18, 1998) (Ecuador); U.N. Conference of Plenipotentiaries on the Establishment of an International Criminal Court, ๆ I 21, 36, 40, 51, 55, 58, 77, 81, $84,87,89,92,95,101,108,109,112,114,117,120,124,133,136,138,147,149,152,154,158,162$, 167, U.N. Doc. A/CONF.183/C.1/SR.3 (June 17, 1998) (21 (Germany), 36 (Czech Republic), 40 (Malta), 51 (Brazil), 55 (Denmark), 58 (Lesotho), 77 (Republic of Korea), 81 (Poland), 84 (Trinidad and Tobago), 87 (Australia), 89 (UK), 92 (Argentina), 95 (France), 101 (Cuba), 108 (Thailand), 109 (Slovenia), 112 (Norway), 114 (Côte d'Ivoire), 117 (South Africa), 120 (Egypt), 124 (Mexico), 133 (Colombia), 136 (Iran), 138 (US), 147 (Spain), 149 (Romania), 152 (Senegal), 154 (Sri Lanka), 158 (Venezuela), 162 (Italy), 167 (Ireland)); U.N. Conference of Plenipotentiaries on the Establishment of an International Criminal Court, ๆף 2, 4, 7, 8, 11, 12, 13, 14, 15, 16, 17, 18, 19, 20, 21, 23, 25, 27, 29, U.N. Doc. A/CONF.183/C.1/SR.4 (June 17, 1998) (2 (Canada), 4 (Guinea), 7 (Switzerland), 8 (Sweden), 11 (Portugal), 12 (Yemen), 13 (Vietnam), 14 (Netherlands), 15 (Bahrain), 16 (Benin), 17 (Japan), 18 (Bangladesh), 19 (Niger), 20 (Austria), 21 (Uruguay), 23 (Sierra Leone), 25 (Israel), 27 (Chile), 29 (Kenya)); U.N. Conference of Plenipotentiaries on the Establishment of an International Criminal Court, I 51, U.N. Doc. A/CONF.183/C.1/SR.5, (Nov. 20, 1998) (51 (Venezuela)); U.N. Conference of Plenipotentiaries on the Establishment of an International Criminal Court, ๆ 15, U.N. Doc. A/CONF.183/C.1/SR.34 (Nov. 20, 1998) (15 (Jamaica)).

96 U.N. Conference of Plenipotentiaries on the Establishment of an International Criminal Court, ๆף 8, 39, 41, 74, 76, 78-79, U.N. Doc. A/CONF.183/C.1/SR.25 (Nov. 20, 1998) (8 (South Africa), 39 (Mozambique), 41 (Sweden), 74 (Botswana), 76 (Croatia), 78 (Australia), 79 (Senegal)); U.N. Conference of Plenipotentiaries on the Establishment of an International Criminal Court, ๆ『 34-35, 48, 63, U.N. Doc. A/CONF.183/C.1/SR.26 (Nov. 20, 1998) (34 (Uruguay), 35 (Turkey), 48 (Brazil), 63 (Ghana)); U.N. Conference of Plenipotentiaries on the Establishment of an International Criminal Court, ๆ 9 19, 74, U.N. Doc. A/CONF.183/C.1/SR.27 (Nov. 20, 1998) (19 (Nicaragua), 74 (Sri Lanka)); U.N. Conference of Plenipotentiaries on the Establishment of an International Criminal Court, $\uparrow$ 15, U.N. Doc. A/CONF.183/C.1/SR.34 (Nov. 20, 1998) (15 (Jamaica)).

97 SCHABAS, supra note 72 , at 148.

98 William A. Schabas, Unimaginable Atrocities: Justice, Politics, and Rights at the War Crimes Tribunals 6o (2012); Editors, Jurisdiction: Universal Jurisdiction - War Crimes and Crimes against Humanity, 13 Australian Yearbook of INTERNATIONAL LAW 239, 246 (1991). 
IMT focused on the need to show a connection to aggressive wars. ${ }^{99}$ This idea was confirmed by the ILC in its 1950 Nuremberg Principles and its 1950 Draft Code of Offenses. ${ }^{100}$ The drafting history of Article 7 also demonstrates that a nexus with an armed conflict was a legal requirement for the crimes against humanity. These observations show that the Big Bang theory is justified that the notion of crimes against humanity required a nexus with an armed conflict.

As for commentators arguing for the nexus as a jurisdictional requirement in the Nuremberg Charter, it is not necessary to assess when this link disappeared, since it never existed. For other commentators deeming the nexus a substantive legal element, the nexus with an armed conflict disappeared at some time. As observed above, the second viewpoint is the appropriate understanding. Schabas wrote: " $\mathrm{T}]$ he nexus between armed conflict and crimes against humanity that existed at Nuremberg was part of the original understanding, and was only removed at some point subsequent to $19455^{\prime 101}$ Scholars also differ with respect to the disappearance of a nexus with an armed conflict as a legal element at the material time. The sub-question in this section is whether that link with an armed conflict disappeared under customary law before or in 1971. The following paragraphs survey post-Nuremberg instruments, jurisprudence and the attitude of the UN organs to show the existing confusion about determining the moment of the disappearance of the nexus.

As shown above, the text of Control Council Law No. 10 did not refer to the nexus with war. However, in the application of Control Council Law No. 10, the Subsequent Proceedings required a link with an armed conflict. Additionally, the 1950 ILC Nuremberg Principles also upheld the requirement that the underlying acts of crimes against humanity, before or during the war, be connected to aggressive wars. The formulation of crimes against humanity in the 1951 Draft Code of Offences required that "inhuman acts [...] are committed in execution of or in [connection] with other offences defined in this

\footnotetext{
99 France v. Göring, supra note 38, at 184.

100 Jean Spiropoulos (Special Rapporteur), Formulation of the Nürnberg Principles, at 187, U.N. Doc. A/CN.4/22 (Apr. 12, 1950), reprinted in [1957] 2 Yearbook of the International LAW Commission 181, U.N. Doc. A/CN.4/SER.A/195o/Add.1; Draft Code of Offences Against the Peace and Security of Mankind, U.N. A/CN.4/19 (1950), reprinted in [1957] 2 Yearbook of the International LaW Commission 249, U.N. Doc. A/CN.4/ SER.A/1950/Add.1.

101 SCHABAS, supra note 98 , at 59 .
} 
article". 102 This formulation did not substantively remove the armed conflict nexus requirement. ${ }^{103}$ The definition in the 1954 Draft Code of Offences, however, did not follow the essence of the 1951 version on the nexus issue but enlarged the scope of crimes against humanity to cover acts not committed in connection with other offences. ${ }^{104}$ Article $1(b)$ of the 1968 Convention on the Non-Applicability of Statutory Limitations referred to "[c]rimes against humanity whether committed in time of war or in time of peace as they are defined in the Charter of the Nuremberg International Military Tribunal".105 Given its very ratification by States, Article 1(b) of the Convention is less significant evidence to justify that a nexus was not required under customary law in 1968.

Jurisprudence of international and internationalised tribunals also does not show consistency on when the armed conflict nexus disappeared for crimes against humanity. The 2006 Kolk and Kislyiy $v$ Estonia case before the European Court of Human Rights (ECtHR) concerned the punishment against two individuals by Estonia based on the 1994 Estonia Penal Code for crimes against humanity committed in peacetime in 1949. The ECtHR rejected the two individuals' applications because Article $7(1)$ of the European Convention on Human Rights prohibiting retroactive application of crimes under national or international law was not violated. The Chamber of the ECtHR implicitly upheld that by virtue of international law, the prosecution of deportation as a crime against humanity committed in peacetime in 1949 was not a violation

102 Report of the International Law Commission to the General Assembly, at 136, U.N. Doc. A/1858 (1951), reprinted in [1957] 2 Yearbook of the International LaW Commission 123, U.N. Doc. A/CN.4/SER.A/1951/Add.1 (art. 2(10) reads: "Inhuman acts by the authorities of a State or by private individuals against any civilian population, such as murder, or extermination, or enslavement, or deportation, or persecutions on political, racial, religious or cultural grounds, when such acts are committed in execution of or in connexion with other offences defined in this article").

103 Id. at $59,136$.

104 Draft Code of Offences Against the Peace and Security of Mankind, at 150, U.N. Doc. A/ CN.4/85 (1954), reprinted in [1957] 2 Yearbook of the International LaW ComMISSION 112, U.N. Doc. A/CN.4/SER.A/1954/Add.1. Art. 2(11) reads: 'Inhuman acts such as murder, extermination, enslavement, deportation or persecutions, committed against any civilian population on social, political, racial, religious or cultural grounds by the authorities of a State or by private individuals acting at the instigation or with the toleration of such authorities".

105 Convention on the Non-Applicability of Statutory Limitations to War Crimes and Crimes against Humanity, opened for signature Nov. 26, 1968, 754 U.N.T.S. 73 (entered into force Nov. 11, 1970). 
of non-retroactive application of the law. In its logic, international law in 1949 did not require a nexus with an armed conflict for crimes against humanity. ${ }^{106}$

Antonio Cassese criticised the decision in the Kolk and Kislyiy $v$ Estonia case and argued that the link with war was an indispensable element for prohibited acts of crimes against humanity before 1949. In his view, it is "only later, in the late 196 os, that a general rule gradually began to evolve, prohibiting crimes against humanity even when committed in time of peace". ${ }^{107}$ By contrast, the Grand Chamber of the ECtHR in the 2008 Korbely $v$ Hungary case held that the link with an armed conflict "may no longer have been relevant by 1956". 108 Also, a Chamber of the ECCC found that "customary international law between 1975 and 1979 required that crimes against humanity be committed in the context of an armed conflict". 109 The observation on case law shows that different views exist about when the nexus with an armed conflict was or was not relevant.

The UN Secretary-General and the UN Security Council considered that the nexus with an armed conflict was not required for crimes against humanity under customary law in 1993. In 1993, the Report of the Secretary-General on the establishment of the ICTY stated that:

Crimes against humanity were first recognised in the Charter and the Judgement of the Nuremberg Tribunal, as well as in Law No. 10 of the Control Council for Germany. Crimes against humanity are aimed at any civilian population and are prohibited regardless of whether they are committed in an armed conflict, international or internal in character. ${ }^{110}$

A plain reading indicates no nexus with an armed conflict. The SecretaryGeneral held that the nexus with an armed conflict is not required for punishable acts constituting crimes against humanity under customary law. ${ }^{111}$ The Secretary-General, however, proposed interpreting Article 5 of the draft statute of the ICTY by restricting the crime "when committed in armed conflict,

106 Kolkv. Estonia, 20o6-I Eur. Ct. H.R. 399 (2006) (Decision).

107 Antonio Cassese, Balancing the Prosecution of Crimes against Humanity and NonRetroactivity of Criminal Law: The Kolk and Kislyiy V. Estonia Case before the ECHR, 4 Journal of International Criminal Justice 410, 413 (2006).

108 Korbelyv. Hungary, 2008-IX Eur. Ct. H.R. 299, 348 (2008) (Grand Chamber).

109 Co-Prosecutors v. Sary, Case No. oo2/19-o9-2007-ECCC/OCIJ (PTC 145 \& 146), Decision on Appeals by Nuon Chea and Ieng Thir[tie]th against the Closing Order, If 144 (Extraordinary Chambers in the Courts of Cambodia Feb. 15, 2011) (Cambodia).

110 Rep. of the S.C., I 47, U.N. Doc. S/25704 (1993).

111 Id. at 34. 
whether international or internal in character". The Secretary-General may have intentionally "defined the crime in Article 5 more narrowly than necessary under customary international law". ${ }^{12}$ The UN Security Council adopted the draft statute of the ICTY without modification. ${ }^{113}$ In its interpretative clarification of the ICTY Statute, the UK delegation also stated that:

Articles 2 to 5 of the draft [ICTY] Statute describe the crimes within the jurisdiction of the Tribunal. The Statute does not, of course, create new law, but reflects existing international law in this field.... Article 5 covers acts committed in time of armed conflict. ${ }^{114}$

This statement demonstrates that a notion of crimes against humanity in non-international and international armed conflict reflects part of "existing international law". ${ }^{115}$ In addition, the possibility that acts committed in peacetime constitute crimes against humanity under customary law at that time is not excluded. ${ }^{116}$ The Security Council then implicitly confirms the absence of the nexus requirement in adopting the 1994 ICTR Statute. ${ }^{117}$

The 1995 Tadic Appeals Chamber decision has a significant impact on the clarification of the absence of nexus in custom. As mentioned above, the Appeals Chamber in the Tadic decision on jurisdiction observed that the practice of States began to abandon the nexus requirement. The Appeals Chamber was confident in claiming no connection to an armed conflict under customary law in 1993. In its view, offences with no connection to an armed conflict constituted crimes against humanity in 1993, whereas the ICTY only has jurisdiction over crimes against humanity committed in armed conflicts or linked geographically and temporally with an armed conflict. ${ }^{118}$ Subsequent ICTY

\footnotetext{
112 Prosecutor v. Tadić, Case No. IT-94-1, at 141.

113 S.C. Res. 827 (May 25, 1993).

114 U.N. SCOR, 3217 th mtg. at 19, U.N. Doc. S/PV.3217 (May 25, 1993).

115 Id.

116 See also U.N. Secretary-General, 13 n. 9, U.N. Doc. S/25704 (May 3, 1993) ("In this context, it is to be noted that the International Court of Justice has recognised that the prohibitions contained in common article 3 of the 1949 Geneva Convention are based on 'elementary considerations of humanity' and cannot be breached in an armed conflict, regardless of whether it is international or internal in character").

117 But see SCHABAS, supra note 72, at 169.

118 Prosecutor v. Kunarać, Case No. IT-96-23-A, Judgement, ๆ 83 (Int'l Crim. Trib. for the Former Yugoslavia June 12, 2002); Prosecutor v. Šešelj, Case No. IT-o3-67-AR72.1, Decision on Interlocutory Appeal concerning Jurisdiction, I 14 (Int'l Crim. Trib. for the Former Yugoslavia Aug. 31, 2004); Prosecutor v. Šešelj, Case No. IT-03-67-AR72.1, Decision on Motion for Reconsideration of the "Decision on the Interlocutory Appeal concerning
} 
cases upheld the view that there was no nexus with an armed conflict under customary law, at least at the material time in $1993 .{ }^{119}$ The preparatory works of Article 7 of the Rome Statute also demonstrate that States generally recognised the definition of crimes against humanity committed without association with an armed conflict at the 1998 Rome Conference. ${ }^{120}$

To sum up, instruments and jurisprudence after World War II and the view of the UN organs leave the moment of its disappearance more confusing in 1949, 1951, 1956, the 196os, 1968, or later in 1993.

\section{5}

\section{Conclusion}

The International Crimes Tribunals in Bangladesh seek to prosecute crimes against humanity that occurred decades ago in 1971. This article discussed the question of whether the notion of crimes against humanity did require a nexus with an armed conflict under customary law in 1971 from TWAIL perspective. Section II discussed the notion of crimes against humanity in the International Crimes (Tribunals) Act 1973 and analysed the approaches adopted by the Bangladeshi Tribunals in dealing with the nexus issue for crimes against humanity. The 1973 Act did not refer to an armed conflict. In practice, the Bangladesh ICT-1 adopted two methods in dealing with the nexus issue. In the early stage, the ICT-1 construed that crimes against humanity in the amended 1973 Act do not require a nexus with an armed conflict, which is consonant

Jurisdiction" Dated $3_{1}$ August 2004, I 25 (Int'l Crim. Trib. for the Former Yugoslavia June 15, 2006).

119 Prosecutor v. Furundžija, Case No. IT-95-17/1-T, Judgement, \ 59 (Int'l Crim. Trib. for the Former Yugoslavia Dec. 10, 1998); Prosecutor v. Tadić, Case No. IT-94-1-A, Judgment, ๆ ๆ 249, 251 (Int'l Crim. Trib. for the Former Yugoslavia July 15, 1999); Prosecutor v. Kunarać, Case No. IT-96-23-A, Judgement, ๆ ๆ 82-83 (Int'l Crim. Trib. for the Former Yugoslavia June 12, 2002); Prosecutor v. Šešelj, Case No. IT-o3-67-AR72.1, Decision on Interlocutory Appeal concerning Jurisdiction, If 13 (Int'l Crim. Trib. for the Former Yugoslavia Aug. 31, 2004); Prosecutor v. Šešelj, Case No. IT-03-67-AR72.1, Decision on Motion for Reconsideration of the "Decision on the Interlocutory Appeal concerning Jurisdiction" Dated ${ }_{31}$ August 2004, If 21 (Int'l Crim. Trib. for the Former Yugoslavia June 15, 2006); Prosecutor v. Stanišić, Case No. IT-o3-69-T, Judgement, I 960 (Int'l Crim. Trib. for the Former Yugoslavia May 30, 2013).

120 Schabas, supra note 72 , at 147-52; M. Cherif Bassiouni, Crimes Against Humanity: Historical Evolution and Contemporary Application (2011); Christopher K. Hall \& Carsten Stahn, Article 7 Crimes Against Humanity, in CommentaRY on the Rome Statute of the International Criminal Court: Observers' Notes, Article by Article 144, ๆ 1 $^{-29}$ (Otto Triffterer \& Kai Ambos eds., 2nd ed. 2008). 
with customary law. Later on, the ICT-1 simply stressed the fact of war as a background for the prosecution and punishment, leaving the nexus legal issue untouched. However, given the fact that the 1971 liberation war existed as a background, the practice of the ICT-1 would not violate the principle of nonretroactivity. This also assists in understanding why the ICT-1 in its recent judgments do not touch on the nexus issue. By contrast, the ICT-2 held that a nexus with an armed conflict was required in customary law and this element is satisfied in its cases.

Section 3 illustrated how the histories have shaped the concept of crimes against humanity and why it was connected with an armed conflict. In theory, scholars' opinions differ concerning whether a nexus with an armed conflict was a legal element. The Steady State theory argues that the link with an armed conflict was never a legal but rather a jurisdictional requirement imposed by the Nuremberg Charter for the purpose of the Iмт. However, the Big Bang theory holds that the nexus with an armed conflict was a legal requirement before the гмт but disappeared later on. After analysing the jurisprudence of international criminal tribunals and international authorities, this article argues that the armed conflict nexus was a requirement for crimes against humanity. The Big Bang theory seems to be the appropriate interpretation of the nexus issue. As shown above in Section 4, it remains unclear when this nexus had disappeared, in the 196os, 1971, or later on in customary law. Thus, it is uncertain whether the notion of crimes against humanity required a nexus with an armed conflict in 1971.

The background after World War II might account for the disappearance of the nexus for crimes against humanity and why it is unclear when such a nexus had disappeared. On the one hand, the Allies Powers in 1945 introduced crimes against humanity to prosecute crimes committed inside Germany by Germans against its citizens. As observed above, for fear of prosecuting act committed by their government against civilians, a nexus between the crimes with the aggressive war, an international armed conflict, was required. After World War II, these Allied powers tried to reshape the post-war system through the UN. The 1948 Universal Declaration of Human Rights was passed, while the establishment of an international criminal tribunal was delayed for decades until the end of the 1980s. At that time, the issue of extending crimes against humanity to cover crimes committed in civil war or in peace time was less concerned and discussed by these Allied powers. During the last four decades, there were few prosecutions of crimes against humanity in the world. Most prosecution of the crimes committed in the past were brought in recent years.

On the other hand, during the independence movements and the decolonisation period after World War II, many States became independent or 
declared their independence. In addition, the process of decolonisation sometimes involves violence and liberation wars. According to Article 1(4) of 1977 Additional Protocol I to the 1949 Geneva Conventions, the conflicts between the colonial domination and non-State entities in exercising selfdetermination are characterised as international armed conflicts. In this circumstance, European-colonial States are not in the interest of expanding the scope of crimes against humanity by removing the nexus with an international armed conflict. Disassociating the armed conflict nexus was only in the interest of non-State entities in these colonial States and of peoples in new States, in particular those States without political democracy. Over the previous decades, however, there have been few reported cases where domestic courts have prosecuted crimes against humanity committed in conflicts or in peace time. For lack of practice in prosecuting crimes against humanity and opinio juris, it is inappropriate to conclude at what moment the customary rule of crimes against humanity was modified by dismissing the armed conflict nexus. Therefore, it is less agreed that the nexus requirement was removed before or in 1971.

Certain term or norm in European thought is the starting point for the TWAIL analysis. A nexus with an armed conflict for the notion of crimes against humanity was a European-centric idea. However, the issue when this nexus disappeared remains unclear. Practice of post-colonial States may assist in clarifying this issue. It is an opportunity for the Bangladeshi Tribunals to contribute to the clarification of the nexus issue for crimes against humanity. This article concludes that the Bangladeshi Tribunals failed to clarify the nexus issue for crimes against humanity at the material time and that the Tribunals missed the chance to contribute to the clarification of a customary rule. The view of some judgments of the Bangladesh Tribunals is less supported that a nexus of an armed conflict was not required under customary law in 1971. The Bangladeshi Tribunals should be cautious to this legal element as well as the background and considerations of these Allies Powers observed above. Such an analysis in their judgments would improve the soundness of their reasoning and better qualify themselves as relevant State practice for the identification of customary international law. 